\title{
The evolution of hydrothermal alteration in glassy and variably palagonitized Surtsey tuff: an XRPD approach
}

\author{
P. CAPPELLETTI ${ }^{1}$, C. RiSPOLI ${ }^{1 *}$, T.B. WEISENBERGER ${ }^{2}$ \\ and S. PRAUSE ${ }^{2}$ \\ ${ }^{1}$ Dipartimento di Scienze della Terra, dell'Ambiente e delle Risorse \\ (DiSTAR), Università degli Studi di Napoli Federico II \\ ${ }^{2}$ Iceland GeoSurvey (ÍSOR), Reykjavík, Iceland
}

Surtsey volcano represents a world-class example of island formation through rift zone volcanism. In 1965 was declared a natural reserve representing a pristine geological and biological research laboratory and it will continue to be so [1]. The island was first drilled in 1979 , in order to study its structure, the hydrothermal system generated on the island after its formation and the rock alteration processes. In 2017, International Continental Scientific Drilling Program (ICDP), the Surtsey Underwater volcanic System for Thermophiles, Alteration processes and INnovative Concretes (SUSTAIN) project drilled three cored boreholes through the basaltic tuff, tephra, and minor intrusions of Surtsey volcano. The study of these new cores and the comparison between them and the first 1979 core will be very important to improve the knowledge of all the geological and biological processes that happened on the island since its formation until the 2017 drilling and to understand how those processes have developed during the last 50 years [2]. The goal of this study is a first evaluation of the evolution of hydrothermal alteration in glassy and variably palagonitized Surtsey tuff through a comparative XRPD (X-ray powder diffraction) study of samples from cores recovered during the 1979 and 2017 expeditions. Petrographic comparison between the two vertical drills provides new insights into time-lapse evolution of Sutsey hydrothermal system [3]. Alteration was distincted in five zones defined by discrete mineralogical assemblages [3]. XRPD studies will likely confirm petrographic studies and therefore shed new light on the transformation pathways of progressive reactions of sidromelane, evolving in secondary phases (e.g. smectite, zeolite) clearly recognizable from palagonitized glass textures.

[1] http://surtsey.icdp-online.org/. [2] Jackson et al. (2015) Sci. Dril. 20, 51-58. [3] Prause et al., (2020), J. Volcanol. Geotherm. Res 392, 1-8. 